岡山医誌（1990）102，663６78

\title{
TPN 下における糖，脂肪乳剂の至適配合比の検討
}

$-\mathrm{RI}$ 燃焼率, 臓器内分布, 生化学的検查, 窒素出納よりの検討 -

\author{
岡山大学医学部第二外科学教室（指導：寺本 滋教授） \\ 池田昭彦
}

(平成 2 年 3 月 24 日受稿)

Key words : ${ }^{14} \mathrm{C}$ 標識化ブドウ糖, ${ }^{14} \mathrm{C}$ 標識化脂肪乳剂, 脂肪代謝

緒言

高カロリー輸液 Total Parenteral Nutrition (TPN) は現在臨床に広く施行されているが, Non-protein calorie (NPC) としてのエネルギ 一源にアメリカで始められた糖質を用いる中心 静脈栄盖法 $(T P N)^{1)}$ とヨーロッパで開発された 脂肪乳剂を併用する末梢完全静脈栄盖法 $(\mathrm{PPN})^{213)}$ に大別される。本邦では糖質を主体 とする TPN が主に施行きれてきた。糖質，な かんずくブドウ糖が生体のエネルギー代謝の中 心を占めることは広く認められているが, 糖質 のみの TPNにおいては必須脂肪酸久方症(45)67778) を来すことが明らかとなり，また栄養学的にも 糖, 脂肪，アミノ酸の 3 者を併用した方がより 生理的であることより, 脂肪乳剤の併用が勧め られている9.しかしながら，TPN 下において， Non-protein calorie としてのエネルギーである ブドウ糖，脂肪乳戍をどのような配合比で使用 するかは, 未だ諸説(1011112133)があり，明らかとさ れておらず，TPN 下における糖，脂肪のお互い の代謝動態に及はす影響も解決されていない.

そこで TPN 下に糖, 脂肪の配合比を変える ことにより，外因性非蛋白熱源の利用効率がい かに変化するが，また体内でいかなる代徱動態 をしているかを明らかにするため, TPN 下に標 識化脂肪乳刜, 標識化ブドウ糖を投与し, 呼気 排泄 ${ }^{14} \mathrm{CO}_{2}$ 及び䑏器内分布を検討した。 また, 血清生化学的検查, 臟器内脂質量, 肝 ·筋グリ コーゲン量, 肝・筋蛋白量, 窒素出納について も検討を加えたので報告する。
対象と方法

\section{1. 実験モデルの作成法}

1) 実験動物: 体重 $300 \mathrm{~g}$ 前後 $(9 \sim 11$ 週龄) の Wistar 系雄ラットを用いた. ブドウ糖/脂肪 のカロリー比により，A 群 $(100 / 0) ， \mathrm{~B}$ 群 $(80 /$ 20), C 群 $(60 / 40), \mathrm{D}$ 群 $(40 / 60), \mathrm{E}$ 群 $(20 /$ 80の5群に分けた。

2) 中心静脈カテーテル：外径0.044インチの ポリエチレンチューブ (Igarashi No.15) に外 径0.024インチのポリエレンチューフ (Clay Adams Intramedic No. 7400）を接合し，さら にこの先端に外径 0.02 インチのシリコンラバー チューブ (Dow Corning Silastic) を接続し, この先端部を血管内の留置部とした.

3) 中心静脈カテーテル挿入法：ジェチルエ 一テル吸入麻醉下に右側䫫部に小切開を加之総 䫟静脈を露出し，ここよりカテーテルを上大静 脈まで挿入固定した。カカテーテルの反对側は皮 下を通して頸部背側中央に出し，無拘束の 4 点 支持頚皮固定板に接続した Protective coil $の$ 中を通して Swivelに接続した. Swivel の反对 溉はポリエチレンチューブ（外径0.044インチ， Igarashi No. 15）を用いて持続注入ポンプに接 続した。これらのラットを代謝ゲージ内に収容 し，準無拘下に絶水食にて一定速度で持続点滴 を行った。

4) 輸液組成：各群に投与した導入輸液, TPN 輸夜組成を表 1 に示す。これらはフィジオ ソール 3 号®(ミドリ十字),パレメンタール®(森 下製薬)，モリプロン®(森下製薬)，イントラリ 
ポス®(ミドリ十字), シーパラ®(塩野義)にて 調整した。

TPN液はアミノ酸浱度を $3 \%$ と一定にし, 糖, 脂肪のカロリー比により 5 群に分けた。 NPC/N 比は193と一定とし，投与熱量は $300 \mathrm{kcal} / \mathrm{kg} / \mathrm{day}$ とした.なお、ビタミンはシーパラ円1.2ml/day の割合で投与した（表 2).

2 . 実験方法と検查項目（図 1)

24時間絶食後，エーテル麻酔下に中心静脈力 テーテルを挿入し，24時間導入輸液 (120kcal/ $\mathrm{kg} /$ day $) ， 24$ 時間 TPN (300kcal $/ \mathrm{kg} /$ day) を行 った後，TPN 下に $0.96 \mu \mathrm{ci} / \mathrm{ml}$ の $10 \%\left(1-{ }^{14} \mathrm{C}\right)$ リノール酸標識化脂肪乳剂イントラリポス® $1 \mathrm{ml}$ を注入し，以下に述べる方法で24時間経時的に 呼気中 ${ }^{14} \mathrm{CO}_{2}$ を測定した. 呼気中 ${ }^{14} \mathrm{CO}_{2}$ 回收 後, ネンブタール麻酔 $(3.25 \mathrm{mg} / \mathrm{kg})$ 下に開腹し 腹部大動脈より採血し, 自然拍動下に生理食塩 水で霘器灌流を行った後, 臓器採取(肝, 腰方 形筋，後腹膜脂肪組織，脾，肺）を行った。ま た, TPN 下に $1 \mu \mathrm{ci} / \mathrm{ml}$ の10\%標識化ブドウ糖 1 $\mathrm{ml}$ 輸液速度と同一の速度で注入し，24時間経 時的に呼気中 ${ }^{14} \mathrm{CO}_{2}$ を測定した。

1) 呼気中 ${ }^{14} \mathrm{CO}_{2}$ 累積回収率測定 : IsotegenI 型機 ${ }^{14)}$ を用い, 約 $300 \mathrm{ml} / \mathrm{min}$ の流速で空気を

表 1 輸液組成 $(100 \mathrm{~m} \ell)$

\begin{tabular}{|c|c|c|c|c|c|c|}
\hline & & Glucose & Fat & $\begin{array}{l}\text { Amino } \\
\text { acid }\end{array}$ & $\mathrm{NPC} / \mathrm{N}$ & $\begin{array}{l}\text { total } \\
\text { kcal }\end{array}$ \\
\hline \multicolumn{2}{|c|}{ 導入粉液 } & $7.0 \mathrm{~g}$ & $0 \mathrm{~g}$ & \multirow{6}{*}{$3 g$} & 61 & $40 \mathrm{kcal}$ \\
\hline \multirow{5}{*}{$\begin{array}{l}\mathbf{T} \\
\mathbf{P} \\
\mathbf{N} \\
\text { 液 }\end{array}$} & A & $22.0 \mathrm{~g}$ & $0 \mathrm{~g}$ & & \multirow{5}{*}{193} & \multirow{5}{*}{$100 \mathrm{kcal}$} \\
\hline & B & $17.6 \mathrm{~g}$ & $1.6 \mathrm{~g}$ & & & \\
\hline & $c$ & $13.2 \mathrm{~g}$ & $3.2 \mathrm{~g}$ & & & \\
\hline & D & $8.8 \mathrm{~g}$ & $4.8 \mathrm{~g}$ & & & \\
\hline & $\mathbf{E}$ & $4.4 \mathrm{~g}$ & $6.4 \mathrm{~g}$ & & & \\
\hline
\end{tabular}

表 2 TPN 液（NPC\%）

\begin{tabular}{ccc}
\hline & Glucose & Fat \\
\hline A & $100 \%$ & $0 \%$ \\
B & $80 \%$ & $20 \%$ \\
C & $60 \%$ & $40 \%$ \\
D & $40 \%$ & $60 \%$ \\
E & $20 \%$ & $80 \%$ \\
\hline
\end{tabular}

流し，10\%モノエタノールアミン溶液（モノエ タノールアミン $30 \mathrm{ml}$, メチルルソルブ $270 \mathrm{ml}$ ) で $\mathrm{CO}_{2}$ を捕捉し, 標識化化合物注入後 30 分, 1 , $2 ， 3 ， 4 ， 5 ， 6 ， 7 ， 12 ， 24$ 時間で上記溶 液を $1 \mathrm{ml}$ ずつ採取し, NEF-Oxifluor $\mathrm{CO}_{2}$ (New England Nuclear 社) を10ml加之測定試料を調 整した. 放射能は液体シンチレーションカウン ター(Aloka LSC-703)にて5分間計測し, クエ ンチングは外部標準線源チャンネル此法で補正 した。

2) 藏器内 ${ }^{14} \mathrm{C}$ 測定: Packard Oxidizer 306 型を用い, 燃焼法で測定した. ${ }^{14} \mathrm{CO}_{2}$ をCarbosorb $7 \mathrm{ml} て ゙$ 捕捉し, Permafluor V (Packard Instrument） $12 \mathrm{ml}$ 加之測定試料を調整し，液体シン チレーションカウンター(Packard Tricarb 4530) にて 2 分間計測し，クエンチングは外部標準線 源チャンネル比法で補正した。

3) 血清及び臓器生化学的検查：上記実験で 使用したラットとは別のラットを用い，24時間 導入輸液，48時間 TPN を行い，ネンブタール 麻酔 $(3.25 \mathrm{mg} / \mathrm{kg})$ 下に腹部大動脈より採血, 生 理食塩水で䁍器灌流をした後, 贜器採取(肝, 肺，脾，筋）を行った。血糖(BS)，遊離脂肪酸 (FFA)，総コレステロール(TC), リン脂質 $(\mathrm{PL})$, トリグリセリド（TG），インスリン，グルカゴ ンを测定し, 蔵器脂質量, 肝・筋グリコーダン 量, 肝·筋蛋白量を測定した， BS，FFA，TC, PL，TG 㹥自動分析装置にて，インスリン，グ ルカゴンはRIA 2 抗体法にて測定した。䁍器脂 質量は Folch 法占)16〉で，肝・筋グリコーダン 量は Anthrone 硫酸法17) で，肝・筋蛋白量は Biuret 法 ${ }^{18121220221)}$ で測定し, 臟器内含有量は体 重で除した值で比較した。

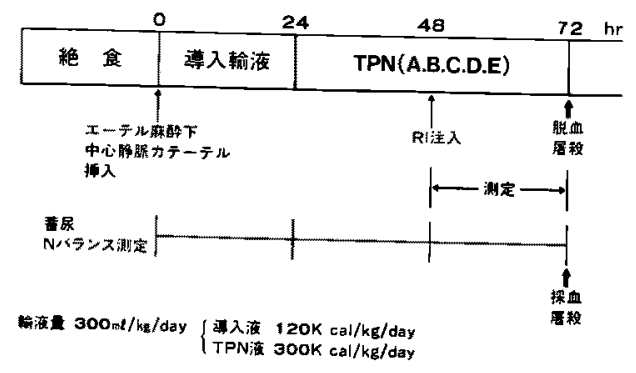

図 1 輸液プロトコール 
表 $3{ }^{14} \mathrm{C}$ ブドウ糖投与後経時的 ${ }^{14} \mathrm{CO}_{2}$ 㹎積回収率（\%)

\begin{tabular}{lrrrrr}
\hline $\mathrm{hr}$ & $\mathrm{A}$ 群 $\mathrm{n}=8$ & $\mathrm{~B}$ 群 $\mathrm{n}=9$ & $\mathrm{C}$ 群 $\mathrm{n}=9$ & $\mathrm{D}$ 群 $\mathrm{n}=9$ & $\mathrm{E}$ 群 $\mathrm{n}=10$ \\
\hline 0.5 & $3.3 \pm 1.9$ & $4.0 \pm 2.0$ & $3.1 \pm 4.5$ & $8.0 \pm 7.9$ & $4.1 \pm 3.4$ \\
1 & $18.9 \pm 6.6$ & $20.4 \pm 6.4$ & $20.1 \pm 9.3$ & $20.3 \pm 8.2$ & $18.6 \pm 8.6$ \\
2 & $43.6 \pm 8.7$ & $47.7 \pm 5.6$ & $44.4 \pm 12.1$ & $43.2 \pm 9.6$ & $41.4 \pm 10.1$ \\
3 & $53.1 \pm 6.7$ & $55.7 \pm 5.8$ & $51.8 \pm 10.3$ & $51.5 \pm 8.7$ & $51.8 \pm 10.1$ \\
4 & $56.4 \pm 5.3$ & $58.1 \pm 5.3$ & $55.9 \pm 9.0$ & $55.7 \pm 7.4$ & $56.7 \pm 10.3$ \\
5 & $58.9 \pm 6.4$ & $60.7 \pm 3.9$ & $58.4 \pm 7.2$ & $58.3 \pm 7.2$ & $58.4 \pm 10.2$ \\
6 & $59.7 \pm 6.0$ & $62.0 \pm 3.9$ & $60.7 \pm 6.4$ & $60.1 \pm 7.0$ & $59.9 \pm 10.5$ \\
7 & $61.6 \pm 6.0$ & $63.7 \pm 4.0$ & $62.1 \pm 5.6$ & $61.3 \pm 7.6$ & $64.1 \pm 10.1$ \\
12 & $66.7 \pm 6.6$ & $67.2 \pm 4.1$ & $65.4 \pm 5.7$ & $66.4 \pm 7.3$ & $71.0 \pm 10.7$ \\
24 & $67.6 \pm 6.5$ & $68.9 \pm 3.6$ & $66.5 \pm 5.6$ & $68.9 \pm 6.2$ & $71.4 \pm 10.5$ \\
\hline
\end{tabular}

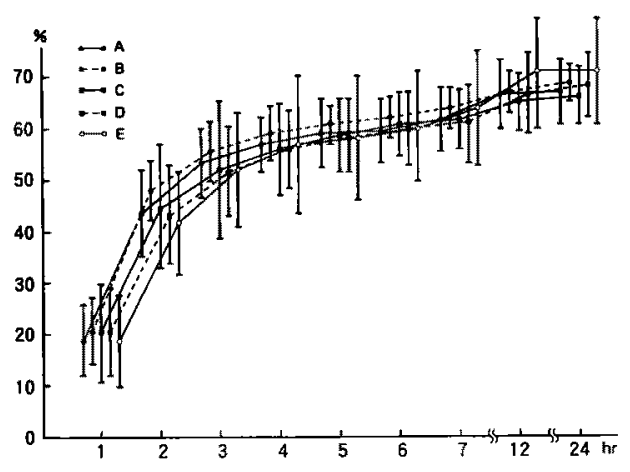

图2 ${ }^{14} \mathrm{C}$ ブドウ糖投与後経時的 ${ }^{14} \mathrm{CO}_{2}$ 累積回収率

4）尿中総窒素：micro-Kjeldahl 法 ${ }^{22)} に て$ 测定した。

5) 統計処理：得られた数值は平均値士標準 偏差で表現し，有意差検定には Student T-test を用い, $\mathrm{p}<0.05$ の時有意差ありとした。

\section{結果}

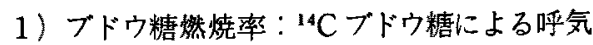
中 ${ }^{14} \mathrm{CO}_{2}$ 累積回収率の測定結果を表 3 , 図 2 に 示す、いずれの群においても投与後 2 時間で急 速に代謝され，その後 5 時間微增していた， 7 時間後の呼気中 ${ }^{14} \mathrm{CO}_{2}$ 累積回收率は $\mathrm{A}$ 群 $61.6 \pm 6.0 \%, \mathrm{~B}$ 群 $63.7 \pm 4.0 \%, \mathrm{C}$ 群 $62.1 \pm 5.6$

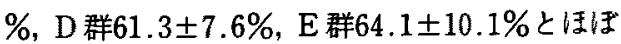
一定の回収率を示し，群間のいずれにも有意差 は認められなかった。 24時間呼気中 ${ }^{14} \mathrm{CO}_{2}$ 累積

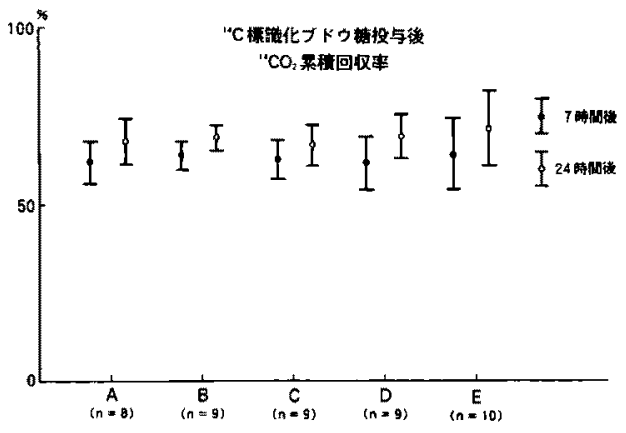

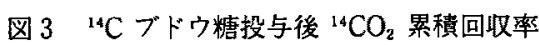

回収率もブドウ糖濃度, 脂肪濃度には影響され ずぼ一定であり，TPN下でもよく利用されて Wた（図 3).

2) 脂肪乳剂燃焼率: ${ }^{14} \mathrm{C}$ リノール酸標識化 脂肪乳剂による呼気中 ${ }^{14} \mathrm{CO}_{2}$ 累積回収率の測定 結果を表 4 ，図 4 に示す．7時間，および24時 間呼気中 ${ }^{14} \mathrm{CO}_{2}$ 累積回収率は全て群間に有意差 がみられた。無脂肪 TPN である A 群では 7 時間㭔気中 ${ }^{14} \mathrm{CO}_{2}$ 累積回収率は $3.1 \pm 1.2 \%$ と著 しく燃焼は抑制されたが，脂肪乳剂配合比が增 えるに従い燃焼率は上昇し，正の相関を示した $\left({ }^{14} \mathrm{CO}_{2}\right.$ 累積回収率: $\mathrm{Y}$, 脂肪配合比： $\mathrm{X} \%$, $\mathrm{Y}=0.35 \mathrm{X}+4.18, \gamma=0.95 ; 7$ 時間, $\mathrm{Y}=$ $0.42 \mathrm{X}+6.05, \gamma=0.97 ; 24$ 時間, 図 5 ). また, $\mathrm{TPN}$ 液でのブドウ糖濃度 $\mathrm{X}$ と脂肪乳剂の燃焼 率 $\mathrm{Y}$ との相関をみると、 7 時間では $\mathrm{Y}=-1.61$ $\mathrm{X}+39.5, \gamma=-0.95,24$ 時間では $\mathrm{Y}=-1.65$ 
表 $4{ }^{14} \mathrm{C}$ 脂肪乳剂投与後経時的 ${ }^{14} \mathrm{CO}_{2}$ 累積回収率（\%）

\begin{tabular}{lccccc}
\hline $\mathrm{hr}$ & $\mathrm{A}$ 群 $\mathrm{n}=7$ & $\mathrm{~B}$ 群 $\mathrm{n}=5$ & $\mathrm{C}$ 群 $\mathrm{n}=11$ & $\mathrm{D}$ 群 $\mathrm{n}=4$ & E群 $\mathrm{n}=17$ \\
\hline 0.5 & $0.1 \pm 0.1$ & $0.7 \pm 0.4$ & $1.6 \pm 0.9$ & $3.0 \pm 0.8$ & $3.0 \pm 1.7$ \\
1 & $0.7 \pm 0.3$ & $4.2 \pm 2.0$ & $6.7 \pm 2.0$ & $12.1 \pm 1.5$ & $11.9 \pm 4.3$ \\
2 & $1.8 \pm 0.9$ & $9.4 \pm 1.9$ & $12.9 \pm 2.3$ & $20.1 \pm 0.8$ & $22.7 \pm 4.4$ \\
3 & $2.3 \pm 1.1$ & $10.7 \pm 1.7$ & $14.5 \pm 2.2$ & $23.0 \pm 1.0$ & $26.0 \pm 4.3$ \\
4 & $2.6 \pm 1.2$ & $11.7 \pm 1.8$ & $15.8 \pm 2.4$ & $24.6 \pm 0.9$ & $28.1 \pm 3.9$ \\
5 & $2.9 \pm 1.3$ & $12.3 \pm 1.7$ & $16.6 \pm 2.2$ & $25.5 \pm 0.6$ & $29.8 \pm 4.1$ \\
6 & $2.9 \pm 1.3$ & $13.0 \pm 2.0$ & $17.3 \pm 2.6$ & $26.4 \pm 0.9$ & $30.9 \pm 4.3$ \\
7 & $3.1 \pm 1.2$ & $13.2 \pm 1.9$ & $18.0 \pm 2.4$ & $27.5 \pm 0.9$ & $31.4 \pm 4.2$ \\
12 & $3.8 \pm 1.6$ & $14.8 \pm 1.7$ & $20.6 \pm 2.6$ & $31.5 \pm 1.2$ & $35.0 \pm 4.2$ \\
24 & $4.3 \pm 1.8$ & $16.7 \pm 2.0$ & $22.8 \pm 3.0$ & $32.4 \pm 1.1$ & $39.1 \pm 4.6$ \\
\hline
\end{tabular}

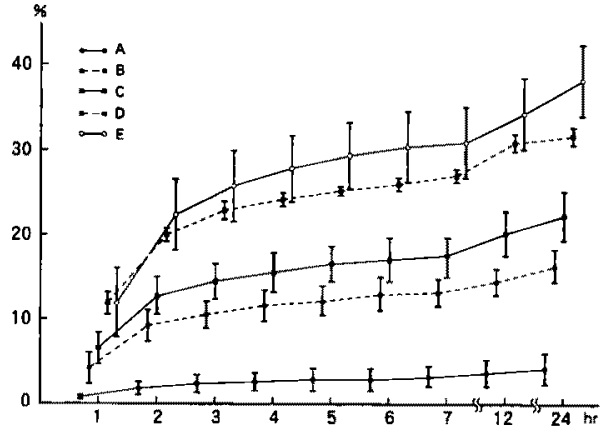

図 $4{ }^{14} \mathrm{C}$ 脂肪乳剂投与後経時的 ${ }^{14} \mathrm{CO}_{2}$ 累積回收率

$\mathrm{X}+43.7, \quad \gamma=-0.96$ と負の相関を示した（図 $6)$.

3）外因性非蛋白熱源の利用効率：困 3, 図 5 に示すごとく,TPN 下においてはブドウ糖が 脂肪乳剂より明らかによく代謝されていた。 た，外因性非蛋白熱源であるブドウ糖および脂 肪乳偊の燃焼力ロリーの合計を求め，これを Non-protein calorie 量 (NPC) で除した值を Total effective NPC ratio ${ }^{23)}$ (ブドウ糖呼気中 ${ }^{14} \mathrm{CO}_{2}$ 累積回収率×ブドウ糖 $\mathrm{Cal} \%+$ 脂肪乳剂 呼気中 ${ }^{14} \mathrm{CO}_{2}$ 累積回収率 $\times$ 脂肪乳剂 $\mathrm{Ca} \%$ ）之 仮称したが，これは脂肪配合比の增加（ブドウ 糖浱度の減少）と共に低下し負の相関を示した (Total effective NPC ratio: Y, 脂肪配合 比: $\mathrm{X} \%, \mathrm{Y}=-0.30 \mathrm{X}+59.7, \gamma=-0.97$ ； 7 時間, $\mathrm{Y}=-0.28 \mathrm{X}+64.6, \gamma=-0.94 ; 24$ 時間, 図 7 )。

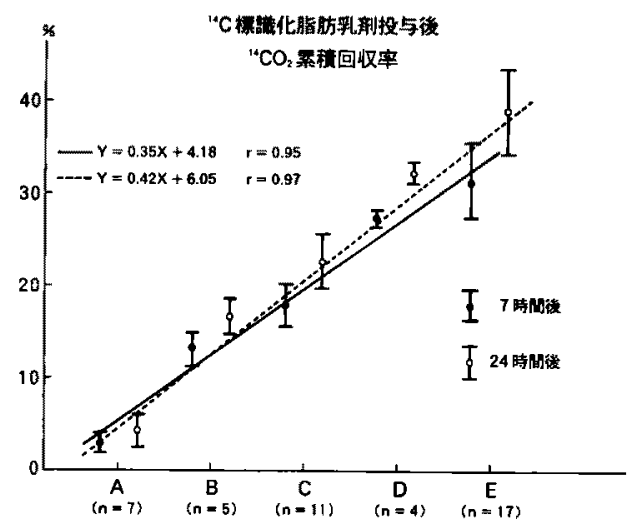

図 $5{ }^{14} \mathrm{C}$ 脂肪乳剂投与後 ${ }^{14} \mathrm{CO}_{2}$ 累積回炚率

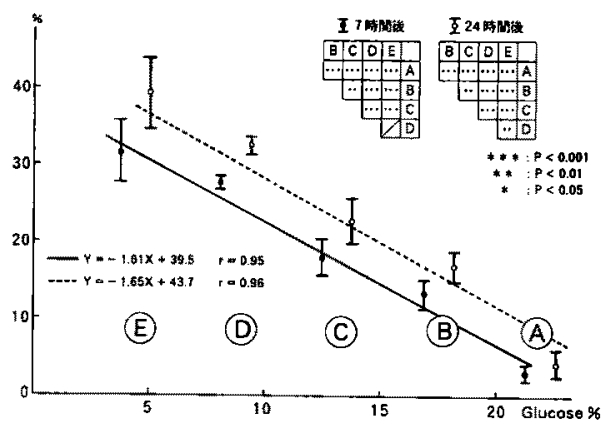

図6 ${ }^{14} \mathrm{C}$ 脂肪乳剂投与後 ${ }^{14} \mathrm{CO}_{2}$ 累積回収率

4）標識化脂肪乳剂投与 24 時間後荿器内 ${ }^{14} \mathrm{C}$ 分布：臟器内 ${ }^{14} \mathrm{C}$ 分布怡脂肪組織内に最当多人, A 群 $64.9 \pm 14.2 \%$ ，B 群 $66.3 \pm 19.9 \%$ ，C 群 


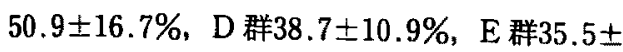
$7.0 \%$ と脂肪の配合比の増加に従って低下してお $\eta$, 䁤器内 ${ }^{14} \mathrm{C}$ 分布 $\mathrm{Y} \%$ と脂肪配合比 $\mathrm{X} \%$ は $\mathrm{Y}=-0.401 \mathrm{X}+67.21, y=-0.70$ と負の相関

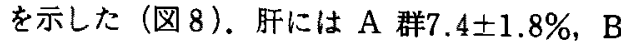

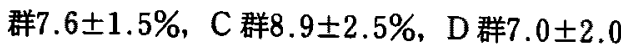
\%, E 群6.5土2.1\%が分布しており，C 群が最 も多く, $\mathrm{E}$ 群が最も少なく而群間には有意差 $(\mathrm{p}<$ 0.05)がみられた（図 9)。筋には A 群5.8 0 0.6

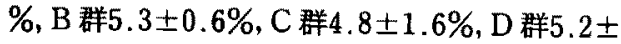
$2.3 \%$ ，E群 $4.2 \pm 1.0 \%$ が分布しており，群間に 有意差は認められなかった（図 9)。脾には $A$ 群 $0.22 \pm 0.05 \%$, B 群 $0.24 \pm 0.11 \%$, C 群 $0.11 \pm$ $0.03 \%, \mathrm{D}$ 群 $0.10 \pm 0.03 \%$, E 群 $0.11 \pm 0.03 \%$

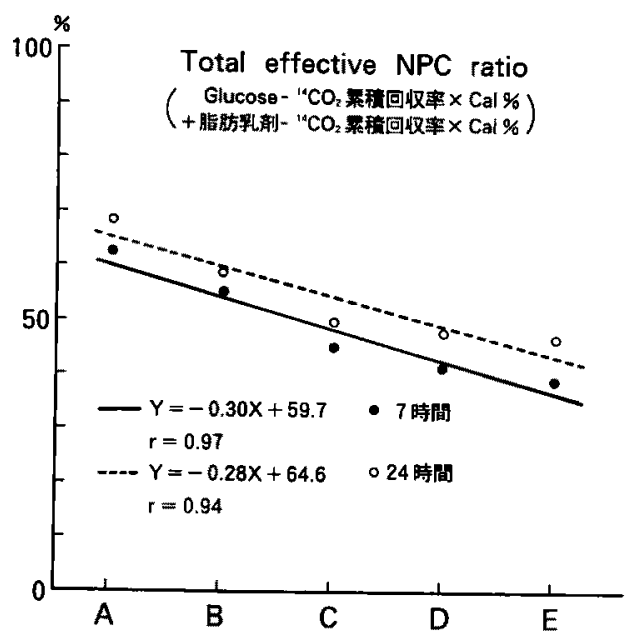

図 7 外因性非蛋白熱源の利用効率

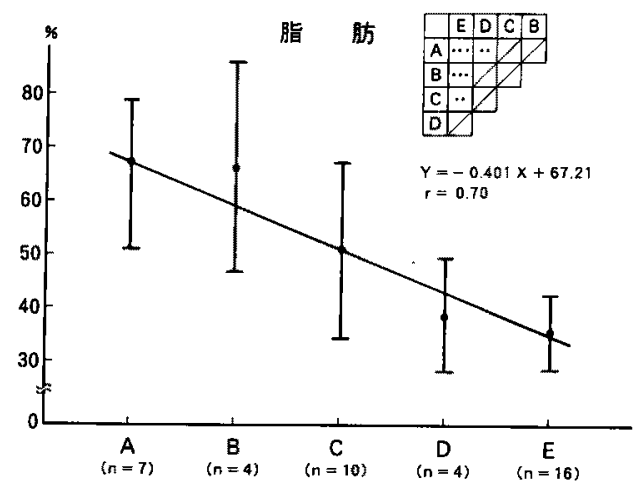

図 $8{ }^{14} \mathrm{C}$ 脂肪乳剂投与後の脂肪組織内 ${ }^{14} \mathrm{C}$ 分布
が分布しており A，B 群は C，D，E群より多 く分布していた(図10)。肺には A 群0.28 0.12 $\%$, B 群 $0.25 \pm 0.16 \%, C$ 群 $0.11 \pm 0.45 \%, D$ 群 $0.14 \pm 0.02 \%, \mathrm{E}$ 群 $0.19 \pm 0.07 \%$ が分布して おり，A，B 群は C, D, E 群上り多〈分布し ていた（四10).

5) 血清総コレステロール (TC) : 血清 TC は脂肪の投与量と正の相関を示し（血清コレス テロール值： $\mathrm{Y}$, 脂肪配合比: $\mathrm{X} \%, \mathrm{Y}=3.22$ $\mathrm{X}+119.8, \gamma=0.89)$ ，各群間に有意差がみら れた(図11).

6) 血清りン脂質 (PL)：血清 PLは脂肪の 投与量と正の相関を示し (血清PL : Y, 脂肪配 合比: $\mathrm{X} \%, \mathrm{Y}=8.82 \mathrm{X}+113.5, \gamma=0.90)$, 各群間に有意差がみられた（図11）。

7）血清トリグリセリド（TG）：血清 TGは $\mathrm{C}$ 群が37.5 $\pm 8.4 \mathrm{mg} / \mathrm{dl}$ と最も低值をとり他の全

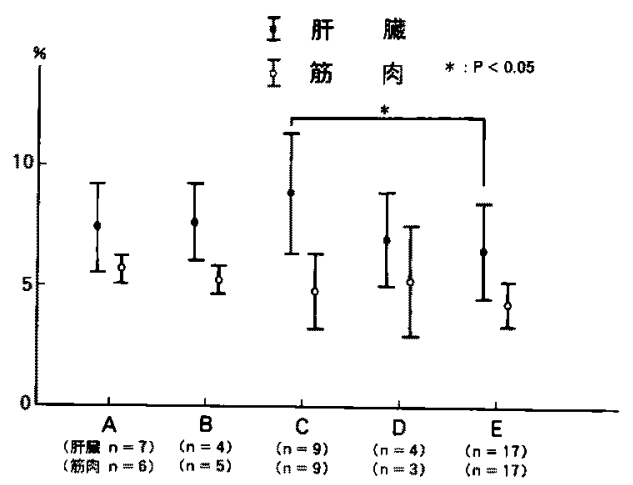

图 $9{ }^{14} \mathrm{C}$ 脂肪乳剂投与後の肝内，筋肉内 ${ }^{14} \mathrm{C}$ 分布

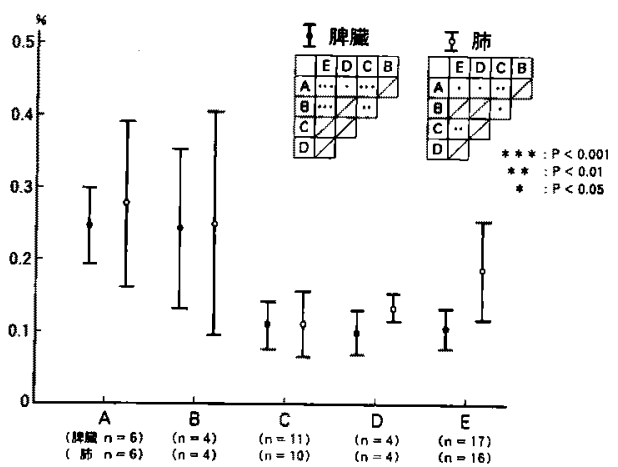

图10 ${ }^{14} \mathrm{C}$ 脂肪乳剂投与後の脾内, 肺内 ${ }^{14} \mathrm{C}$ 分布 
ての群との間に有意差がみられまた $\mathrm{E}$ 群は $111.4 \pm 28.4 \mathrm{mg} / \mathrm{dl}$ と有意に高値をとった(図11)。

8）血清遊離脂肪酸（FFA）：血清 FFAは, $\mathrm{A}, \mathrm{B}, \mathrm{C}$ 群間に有意差はみられないが $\mathrm{D}, \mathrm{E}$ 群 はこれらと比し有意に $(\mathrm{p}<0.001)$ 高值をとっ た（図12）。

9) 血糖(BS)：BSは C 群か $101.1 \pm 19.0 \mathrm{mg} /$ $\mathrm{dl}$ と最も低値をとり，E群が高値をとり両群間 には有意差（p<0.01）がみられた（図12）.

10）インスリン：インスリンは脂肪配合比の 増加と共に低下しておう，E群は A，B 群に比 し有意に低值をとった（図13）。

11）グルカゴン：グルカゴンは C 群が53.0土 $18.4 \mathrm{pg} / \mathrm{ml}$ と A， B，D群に比し有意に低值をと った (図13).

12）臓器内脂質：肝内総コレステロール(TC) は 5 群間に有意差はなく，肝内リン脂質 (PL) も有意差はみられなかったが $\mathrm{E}$ 群が他の群と比 しやや高値をとった，肝内遊離脂肪酸 (FFA) は脂肪投与量の增加に伴い上昇していた，肝内
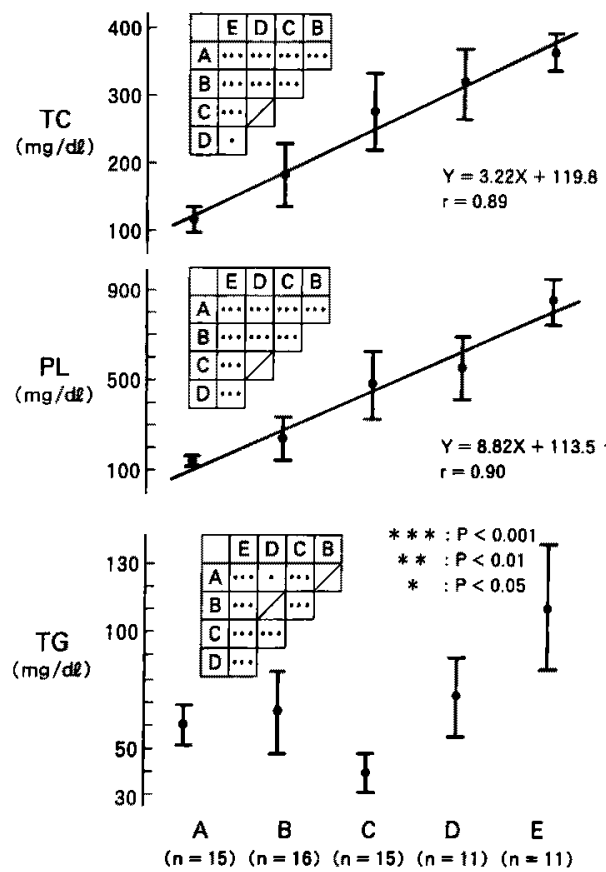

図11 血清総コレステロール、リン脂質、トリグリ セリド
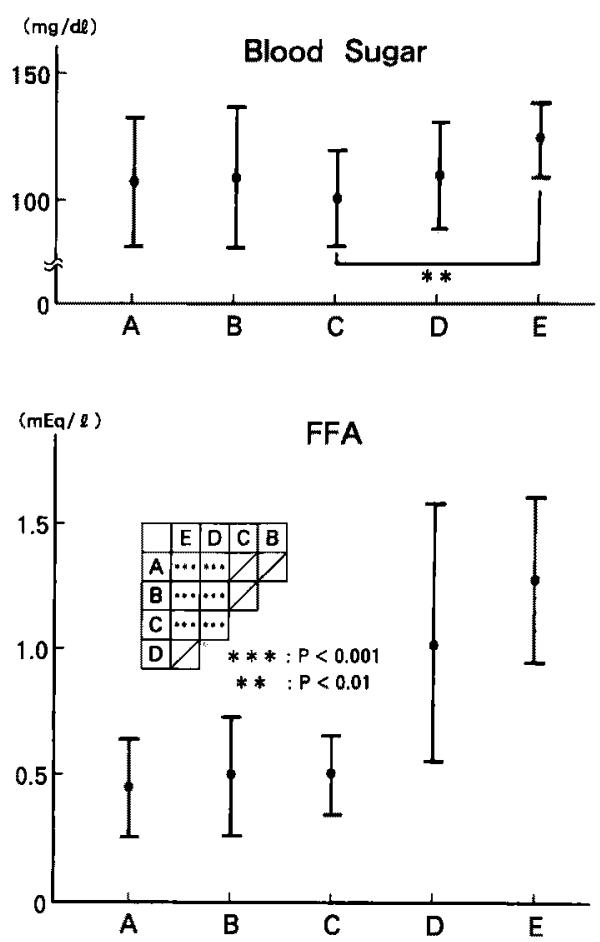

图12 血糖，血清遊離脂肪酸
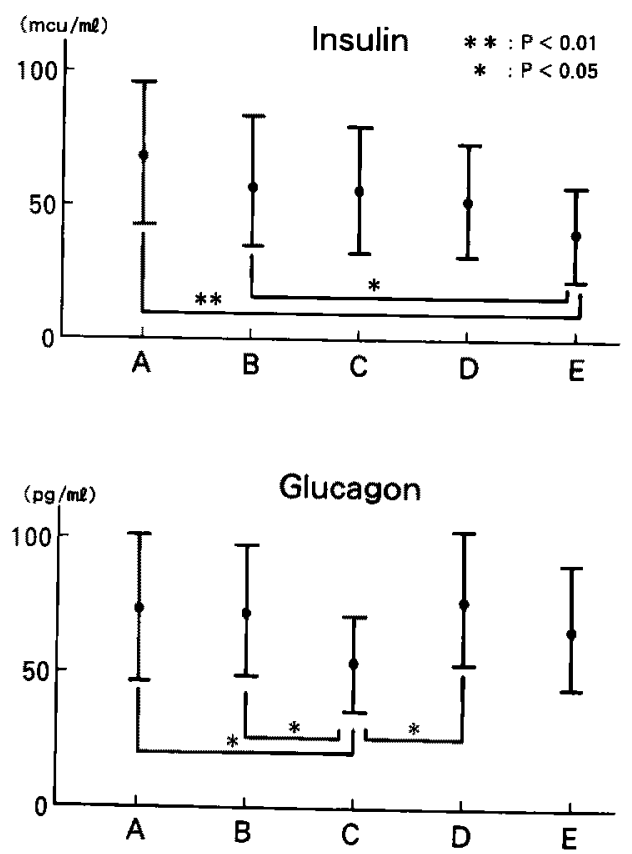

図13 インスリン,グルカゴン 
トリグリセリド（TG）は A 群が他の4 群と比 し著しく高值をとったが, バラツキが大きく有 意の差はみられなかった。た,肝内総脂質 $(T L)$ は 5 群間に有意差はみられなかった(図14,15)。 肺内 TC は D, E 群が A, B, C 群と比し高 值をとり， D 群と $\mathrm{A} ， \mathrm{C}$ 群， $\mathrm{E}$ 群と $\mathrm{A} ， \mathrm{C}$ 群間

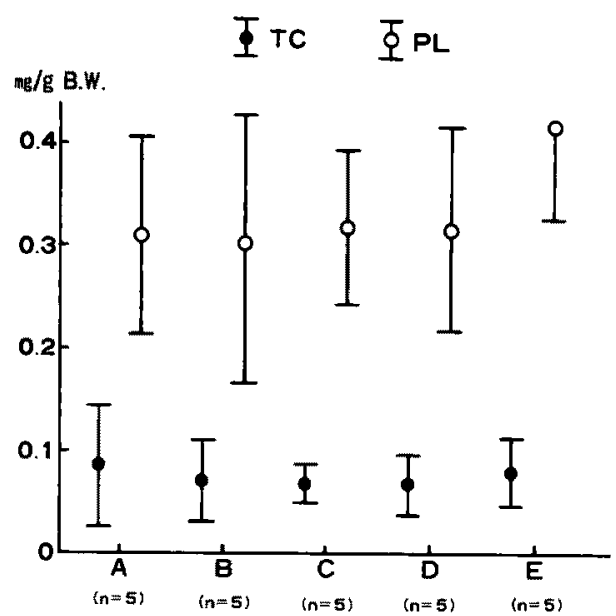

図14 肝内脂質量
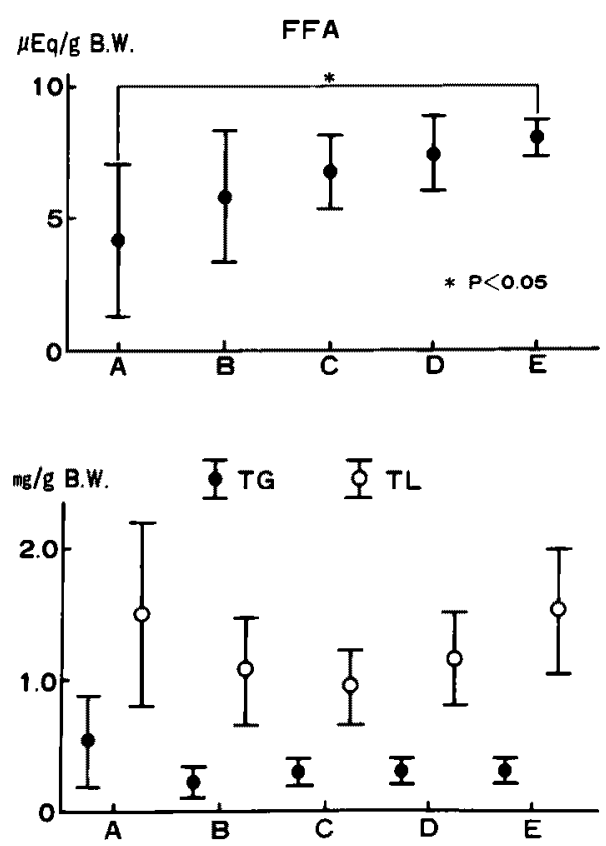

図15 肝内脂質量
に有意差がみられた，肺内 PLもほぼ同様の傾 向を示した。肺内 FFA は D, E 群が A, B, $\mathrm{C}$ 群より高陋をとり D 群と $\mathrm{A}, \mathrm{C}$ 群, $\mathrm{E}$ 群と $\mathrm{A}, \mathrm{B}, \mathrm{C}$ 群間に有意差がみられた。肺内 $T G$ は

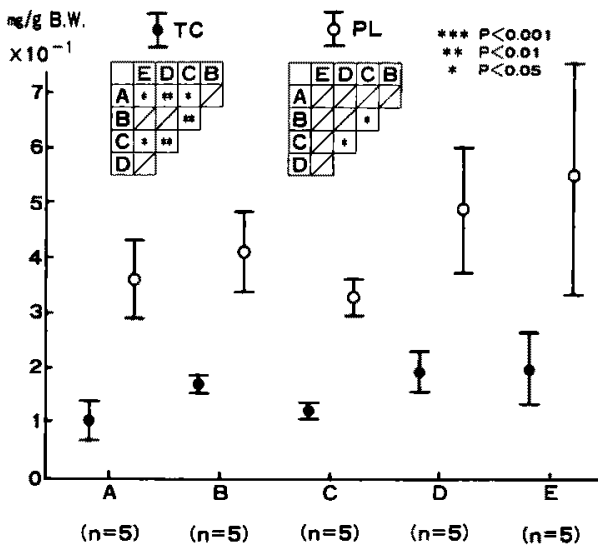

図16 脯内脂質量
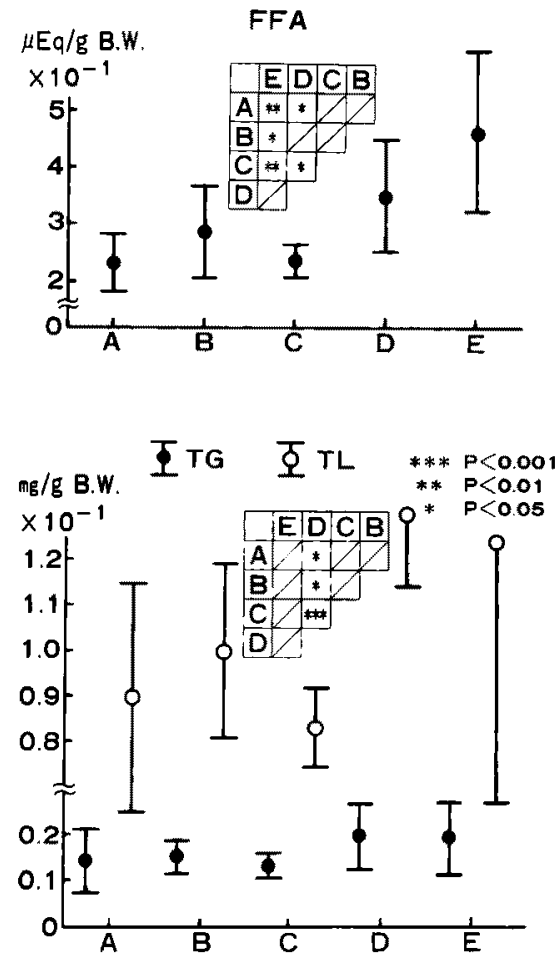

図17 肺内脂質量 
5 群間に有意差はみられなかった。肺内 TLは $\mathrm{D}, \mathrm{E}$ 群が A， B，C群に比し高值をとり，D群 と $\mathrm{A} ， \mathrm{~B}, \mathrm{C}$ 群間は有意差がみられた（図16, 17).

脾内 $\mathrm{TC}$ は $\mathrm{A}$ 群が最も低く, D, E 群は $\mathrm{A}$, $\mathrm{C}$ 群より高值をとり，A 群と B， D， E 群間に
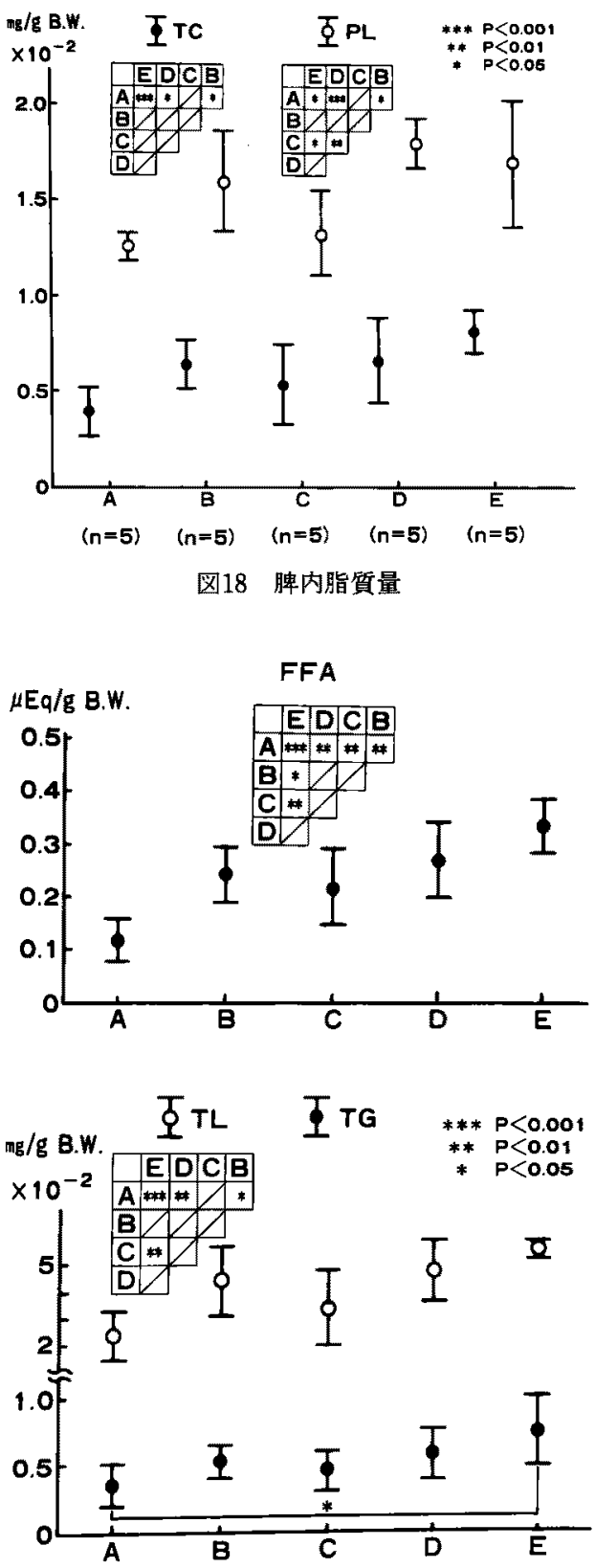

困19脾内脂質量
有意差がみられた，脾内 PLもA 群が最も低 値をとり， $\mathrm{A}$ 群と $\mathrm{B}, \mathrm{D}, \mathrm{E}$ 群間に有意差がみ られた。また $\mathrm{D}, \mathrm{E}$ 群は $\mathrm{A}, \mathrm{B}, \mathrm{C}$ 群より高值 をとり， A，C 群との間に有意差がみられた。 脾内 FFA は， A 群が最も低值をとり，他の 4 群との間に有意差がみられた，E群は最も高值 をとり，A，B，C 群との間に有意差がみられ た。脾内 $\mathrm{TG}$ は $\mathrm{A}$ 群が最も低く， $\mathrm{E}$ 群が最も 高值をとり再群間には有意差がみられた，脾内 TLは A 群が最も低く，D， E 群は A， B，C 群に比し高值をとった。 A 群と B, D, E 群, $\mathrm{C}$ 群と $\mathrm{E}$ 群との間には有意差がみられた図18, 19).

筋肉内 TC, PL，TG，FFA，TL 全て群間 に有意差なく，脂肪投与量の多少にかかわらず， 筋肉内脂質量はほぼ一定であることが示された (困20, 21).

13）肝および筋肉内グリコーゲン量：肝およ び筋肉内グリコーゲン量は $\mathrm{A}, \mathrm{B}, \mathrm{C}$ 群が $\mathrm{D}$, $\mathrm{E}$ 群より高値をとり，肝内グリコーゲン量は $\mathrm{A}$ 群と $\mathrm{E}$ 群， $\mathrm{C}$ 群と $\mathrm{D}, \mathrm{E}$ 群間に，筋肉内グリ コーゲン量は $\mathrm{A}, \mathrm{C}$ 群と $\mathrm{D}, \mathrm{E}$ 群間に有意差が みられた（図22）。

14）肝および筋蛋白量：肝蛋白量は全群間に 有意差はみられなかった。筋蛋白量は $\mathrm{E}$ 群が $\mathrm{B}$

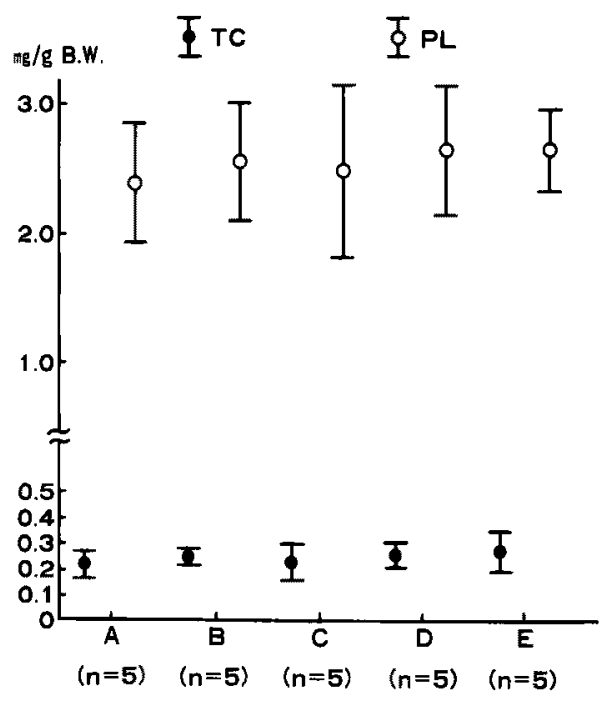

図20 筇肉内脂質量 
群に比し有意に低值をとった（図23）.

15）窒素出納：輸液開始後 3 日間全尿を採取 し, micro-Kjeldahl 法22)にて窒素排泄量を測定 した，図24に示すごとく，TPN 1 日目で A, $\mathrm{B}, \mathrm{C}$ 群は $\mathrm{D}, \mathrm{E}$ 群より $\mathrm{C}, \mathrm{D}$ 群間を除き有意 に良好な窒素出納を示し, TPN 2 日目でも A, $\mathrm{B}, \mathrm{C}$ 群は D, E 群より良好であった。また TPN 48時間の累積窒素出納をみると，A，B，C 群間
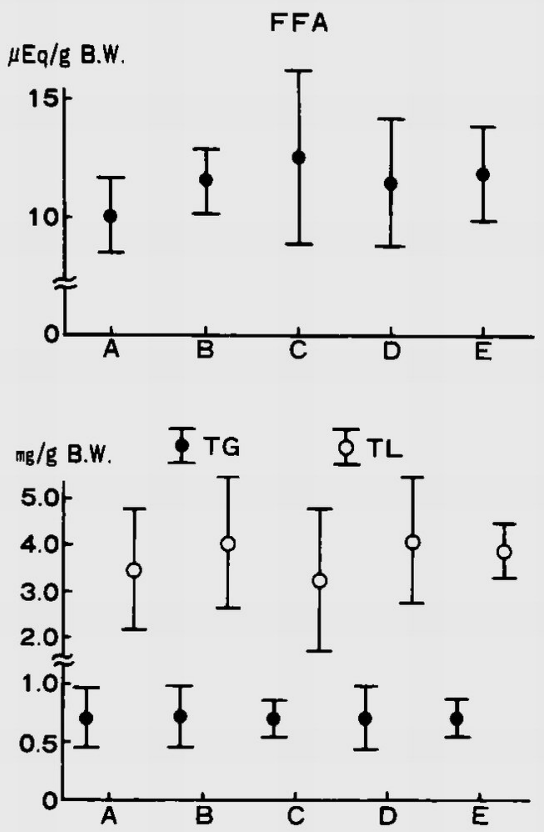

図21 筋肉内脂質量

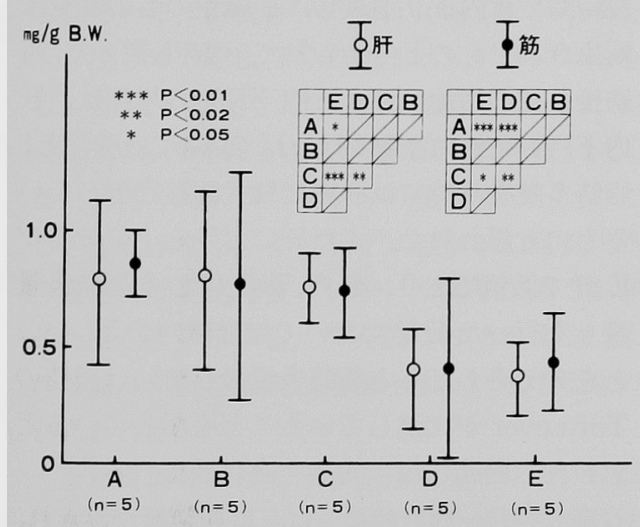

図22 肝，筋肉内グリコーゲン量
に有意差なく, D, $\mathrm{E}$ 群は他の 3 群と比し有意に 低值をとった $(\mathrm{p}<0.001$, 図25).

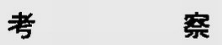

近年外科的栄盖の最も有力な方法となった TPNは急速に普及している.ほぼ満足すべき効 果は認められているが、その組成についてはま だ問題は残されている，特に糖，アミノ酸，脂 肪についての研究は多くみられるが, NPCであ る糖質, 脂肪の配合比については未だ意見の一 致をみておらず, 糖質, 脂肪相互の関係につい ての研究 ${ }^{24 / 25)}$ も散見されるにすぎない.また ${ }^{14} \mathrm{C}$ 標識化ブドウ糖及び脂肪乳剂を用いた研究は多

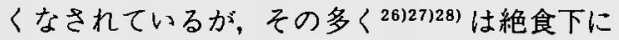
single injection されたものであり，TPN 下で の各種熱源の相互の影響を正確に反映したもの

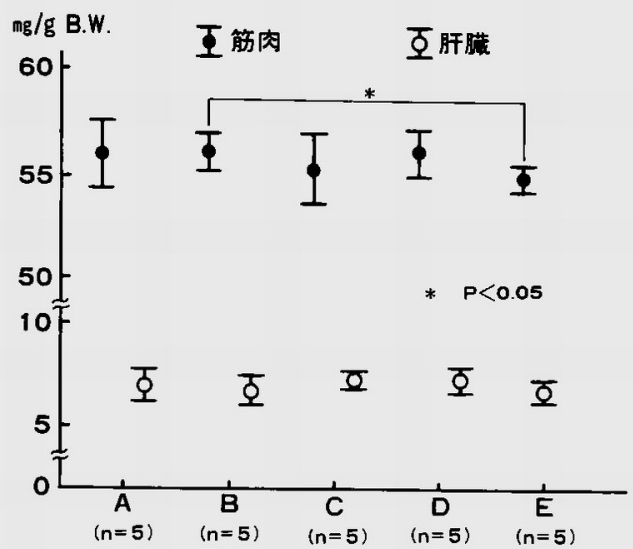

図23肝, 筋肉内蛋白量

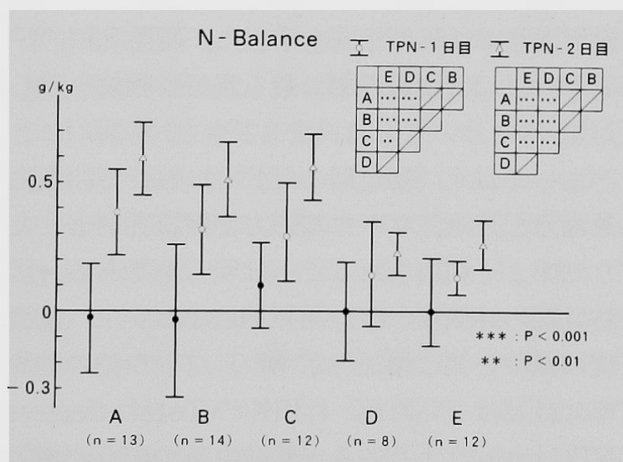

図24 窒素出納 


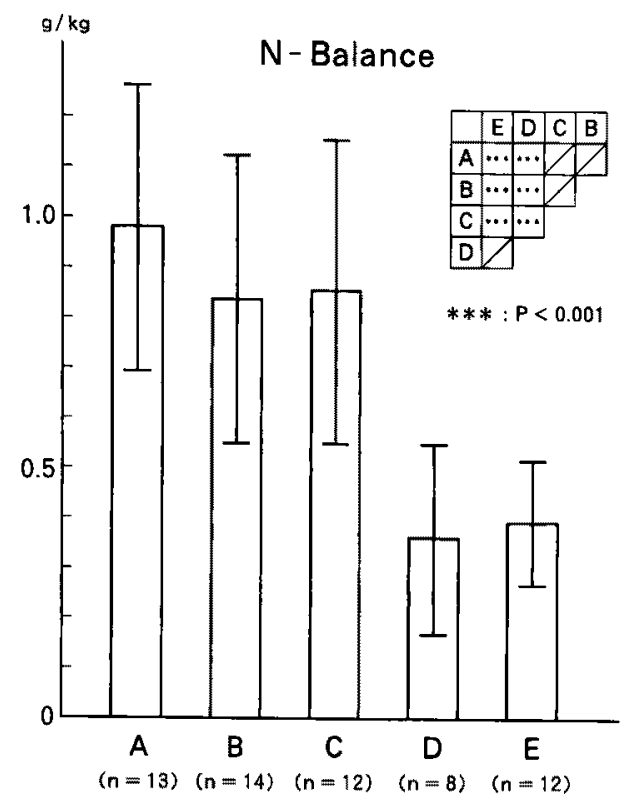

図25累榡堂素出納

とは言えない，教室の石川ら が開発した Isotegen-I 型機を用いることにより，持続 TPN 下に ${ }^{14} \mathrm{C}$ 標識化化合物を投与し呼気中 ${ }^{14} \mathrm{CO}_{2}$ 回 収率を测定することができ，TPN下におけるエ ネルギーの利用効率を正確に把握しえた。

ブドウ糖の7 時間呼気中 ${ }^{14} \mathrm{CO}_{2}$ 累積回収率は $62.6 \pm 6.9 \%$ とほぼ一定の值を示し，群間に差は みられず，ブドウ糖は脂肪乳剂の配合の多少に かかわらず良く利用されていることを示してい る.これに対し, 脂肪の呼気中 ${ }^{14} \mathrm{CO}_{2}$ 累積回収 率は糖濃度の高いものほど著明に抑制されてお $\eta{ }^{25)}$, 脂肪の配合比之脂肪乳剂の呼気中 ${ }^{14} \mathrm{CO}_{2}$ 累積回収率は正の相関を示した。脂肪乳剂の呼 気中 ${ }^{14} \mathrm{CO}_{2}$ 累積回収率は最も良好な燃焼を示し

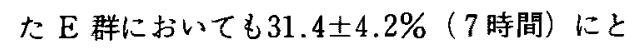
どまっており，安定期の TPNにおける非蛋白 熱源としては，ブドウ糖の方が脂肪乳剂上りよ ク効率よく利用されることは明らかである。脂 肪乳剤の呼気中 ${ }^{14} \mathrm{CO}_{2}$ 累積回収率はブドウ糖濃 度の減少と共に增加を示すが，プドウ糖の燃焼 率には及ばないため, 外因性の Total effective

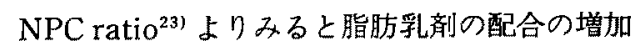
に伴い明らかに低下を示している。しかしなが
ら窒素出納がこれと平行して推移せず， A， B, C 群はほぼ同一で，D，E群で著しく低下してい ること, 肝・筋グリコーゲン量が $\mathrm{D}, \mathrm{E}$ 群で著 しく低下していることより，B，C群においては， 外因性非蛋白熱源の燃焼の差を, 内因性脂質の 燃焼で代償しているものと考えられた。

大内ら ${ }^{29)}$ は TPN 時に扔ける脂肪組織の変化 について検討し, 同カロリーで50\%脂肪併用 TPN 群は無脂肪 TPN 群に比し脂肪組織重量は減少 し，TL 量，TG 量は有意の低値を示したと報 告しており，著者の実験結果と併せて考えると 脂肪併用 TPN は無脂肪 TPN と比し, 内因性 脂肪をより良く利用しているのではないかと考 えられた。また標識化脂肪乳剂を用いた臟器の ${ }^{14} \mathrm{C}$ 分布は, single injectionにおいて大柳ら ${ }^{28)}$ も検討しているが，投与24時間後では我々と同 じく脂肪組織内に最も多く認められていた。 今 回の TPN 下における検討では脂肪組織内 ${ }^{14} \mathrm{C}$ は脂肪の投与量の增加に従って低下しており， これは呼気中 ${ }^{14} \mathrm{CO}_{2}$ 回収率より脂肪の燃焼率の 差によるものと考之られ，投与された余剩の脂 肪は主として脂肪組織内に貯蔵されることを示 している。また肝においてはC群が8.9土2.5\% と最も多く $\mathrm{E}$ 群が $6.5 \pm 2.0 \%$ と最も少なく，両 群間に差がみられた。また肝内 TLは群間に有 意差がなく, 肝内 $\mathrm{TG}$ も $\mathrm{B}, \mathrm{C}, \mathrm{D}, \mathrm{E}$ 群間に はとんど差がみられず，脂肪多量投与時におい ても投与された脂肪は肝内に沈着しないことが 示された. FFA は体内での half life が2 分前 後と短〈 ${ }^{302}$ イントラリピッド中のものは注入後 短時間で体内より消失し, 肝臟中のものは全て 新生されたものと考えられている31).従って,脂 肪投与量の増加に伴う肝内 FFA の増加は, 肝 内 FFA 新生が活発に行われていることを示し, 脂肪多量投与時には肝内脂質代謝は六進してい るものと思われた。また肝における ${ }^{14} \mathrm{C}$ 分布が $\mathrm{E}$ 群で低值であり, 肝内 $\mathrm{TG}, \mathrm{TL}$ が脂肪多量 投与を行った $\mathrm{E}$ 群において增加傾向がそしいこ とを考之合わせると脂肪多量投与時には脂肪の Turn over が元進していることを示していると 思われ, 脂肪代謝の元進を裹付けている。

高カロリ一輸液時にしばしば脂肪肝がみられ， 特にその時の脂質の增加は主として TGの增加 


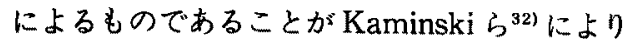
指摘されている。 また無脂肪 TPNにおいては 肝 fatty acid synthetase, acetyl CoA carboxylaseの増加を来し、これが肝 TG 合成につな がク ${ }^{32)}$, 弓狩 ${ }^{33)}$ は不飽和脂肪酸が糖代謝を律速 する glucokinase を阻害すると共に脂肪酸合成 を律速する acetyl CoA carboxylase, G-6-P dehydrogenase を阻害し, 糖よりの脂肪酸合成 を抑制するとしている.このため無脂肪 TPNは 肝内 TG の増加を来し A 群において肝内 TG の増加を来したことと一致した。

肺内 ${ }^{14} \mathrm{C}$ 分布は $\mathrm{A}, \mathrm{B}$ 群が $\mathrm{C}, \mathrm{D}, \mathrm{E}$ 群より 高值をとったが、これは呼気中 ${ }^{14} \mathrm{CO}_{2}$ 回収率よ り脂肪の燃焼率の差によると思われた。肺内脂 質量は脂肪乳剂の投与量の增加に伴い, D, E 群 では堌加していた。

脾内 ${ }^{14} \mathrm{C}$ 分布は $\mathrm{A}, \mathrm{B}$ 群が C, D, E 群より 高值をとったが、これは呼気中 ${ }^{14} \mathrm{CO}_{2}$ 回収率よ り脂肪の燃焼率の差によると思われた。脾内脂 質量は脂肪乳剂の投与量の増加に伴い， D, E 群 では堌加していた。

筋肉内 ${ }^{14} \mathrm{C}$ 分布は群間に差はみられず，脂肪 乳剂投与量の変化にかかわらず，筋肉内 TC, PL，FFA，TG，TLにも差はみられなかった。 このことは脂肪の代謝元進による可能性も考之 られるが，むしろ筋肉内における脂肪の代謝量 が少なく, FFA は筋肉内において $\mathrm{CO}_{2}, \mathrm{H}_{2} \mathrm{O}$ まで代謝されるため脂肪として蓄積されないこ とによるのかもしれない。

血清 TC, PLは共に脂肪投与量と正の相関を 示している。田代ら ${ }^{34335) 36)}$ は10\%イントラリピ ッド投与時の PL, TCの增加はリポ蛋白からみ ると LDLの増加であり，その増加は Lipoprotein -Xそのものであることが強く示唆されたとし， また $20 \%$ イントラリピッドの使用では上記のご とき変化はなく，イントラリピッドの脂質代謝 の変化には乳化卵黄レシチンの関与が強く示唆 されたと述べている。本実験における TC, PL の增加は田代らの実験結果とよく一致するもの と思われる。

また血清 TGは C 群が最も低值をとク，E群 は有意に高値をとっていた，TGは外因性脂肪 由来のものと, 渃より合成されたものがあり $\mathrm{A}$,
$\mathrm{B}$ 群は糖由来の $\mathrm{TG}$ が多く, D, E 群では外因 性脂肪の Over load により TG 高値をとって いるものと思われた，青木 ${ }^{37)}$ は無脂肪 TPNを 行い投与カロリーを增加することにより，血清 TGの上昇と脂肪肝の発生をみることを明らか にしており, Collins ら“は無脂肪 TPN は必 須脂肪酸欠乏症を来し，血清 TG と VLDLの 上昇をみ，脂肪乳剂併用で低下することを示し た. また曽田ら は彽後 1 週間の TPNで無脂 肪 TPNは脂肪併用 TPNより血清 TGが有意 に高値をとることを示している.本実験はTPN が48時間之短いが, 無脂肪 TPN (A 群) はC 群より血清 TGは高值をとっており，脂肪併用 TPNがより生理的であろうと思われた。

Randle ら ${ }^{399}$ は脂肪組織や筋肉より放出され た FFA がブドウ糖の利用の節約を来すこと， また,ブドウ糖捸取により脂肪組織内 TGから のFFA の遊離が抑制されることを示し、これ を glucose fatty-acid cycle という概念にまと めている。また。糖質の欠之により FFA が血 中に放出され, catabolic hormone - エピネフ リン,グルカゴン等ももエネルギ源としてFFA を血中に放出することを示した，D，E群におい て FFA が有意に高值をとることは，脂肪代謝 の六進を示していると共に，相対的な糖質不足 になっていることと catabolic hormone の過剩 分泌により相対的な異化元進状態になっている ことを示していると考えられた。

血糖は C 群が最も低く、ブドウ糖投与量が少 ないにもかかわらず $\mathrm{E}$ 群が高值をとった。

糖，脂肪代謝に影響を及ぼすインスリング ルカゴンの検討では，インスリンは糖濃度の低 下と共に低下していたが、グルカゴンはC 群が 最も低值をとった、一般的に言之ば，インスリ ンは同化を促進する方向に，グルカゴンは異化 を促進する方向に働く $\mathrm{D}, \mathrm{E}$ 群ではインスリン の低下,インスリン/グルカゴン比の低下があり， 全体の同化反応には不利となっている。またグ ルカゴンは肝グリコーゲン分解作用, 糖新生作 用があり40)，D， E 群ではインスりンの低值とあ いまって肝グリコーダン量の低下, 窒素出納の 悪化を来したものと思われる。

飢餓時の初期反応は，血中グルコースの軽度 
低下，血中インスリンの軽度低下，グルカゴン の上昇がみられ、インスリン低下により Lipolysis と Proteolysis が促進し，一方，グルカゴン上 界により Glycogenolysis と Gluconeogenesis が促進されることが示されており ${ }^{41423}$, 本実験の $\mathrm{D}, \mathrm{E}$ 群の代謝動態はこれに類似していると考之 られた。また群の高血糖の機序は明らかでは ないが, FFAが有意に高值をとること、インス リン/グルカゴン比が低下していることなどより， 相対的な異化え進状態になるためと思われた。 本実験と同椂の実験系で石田は標識化アラニン を用い呼気中 ${ }^{14} \mathrm{CO}_{2}$ 累積回収率を測定し，E 群 のみが他の群より有意に低值をとることを示し， $\mathrm{E}$ 群のように脂肪が $80 \%$ を占める TPN 下では 外因性アミ/酸を利用する能力が低下するほど 生体の状㦔が悪化していると推定している ${ }^{43}$.

蛋白節減効果については室素出納の上でA, $\mathrm{B}, \mathrm{C}$ 群間に有意差なく，D， E 群红有意に不良 であった、このことは前記のごとく， D, E 群は 飢餓時の代謝動態に類似し, A, B, C 群に比し 異化穴進，同化抑制があると思われた。脂肪乳 剤の蛋白節減効果については未だ意見の一致を みていないが，多くは脂肪乳戍はブドウ糖に匹 敵する効果があるとしている早/44:45/46). 特に Jeejeebhoy9) はカロリーの83\%を脂肪乳剂で投 与し, 血中の脂質やホルモンは糖単独のTPN と は異なるが窒素出納や箭肉でのアミ/酸攝取は 両者に差を認めていない。また曾田は脂肪併用 TPN を術後施行し検討を加え, 空素出納は糖質 配合夜よりやや少るが血清蛋白，アルブミン， rapid turnover protein は脂肪群の方が侵襲に よる減少を抑制する傾向があることを認めてい $3^{38)}$.

肝および筋ブリコーゲンは A， B，C群がD， $\mathrm{E}$ 群より高值をとっており，外因性非蛋白熱源 の利用は糖質が多いはど良好であり，D，E群は 脂肪投与量が過量のため飢餓に近い状態となっ ており，肝および筋肉内グリコーゲンを消費し ているものと考之られた。

肝の蛋白量は群間に有意差はみられなかった が、これは TPN 期間が短かったため, 窒素出 納が蛋白量に反映していないのではないかと考 えられた。筋蛋白量は $\mathrm{E}$ 群が低值をとり， $\mathrm{B}$ ，
$\mathrm{E}$ 群間に有意差がみられており，窒素出納が脂 肪過量投与で不良となることを反映していると 考えられた。

結語

TPN 下における糖, 脂肪の相互の代謝に及ば す影響と糖，脂肪の至適配合比を明らかにする ため, TPN 液のブドウ糖/脂肪のカロリー比に より 5 群に分け，各群に TPN 下に標識化ブド 门糖, 脂肪乳剂を投与し, 呼気中 ${ }^{14} \mathrm{CO}_{2}$ 累積回 収率, ${ }^{14} \mathrm{C}$ の藏器内移行を測定すると共に血清お よび藏器生化学検査, 窒素出納についても检討 を加え，以下の結論を得た。

1）ブドウ糖の燃紸はブドウ糖濃度, 脂肪濃 度にも影響されず一定であった。

2) 脂肪の燃焼はブドウ糖曟度に比例して抑 制を受けた。

3) Total effective NPC ratio でみると安 定期は糖質の配合比が多いほど，外因性非蛋白 熱源の利用が良好であることが示された。

4）RIの藏器内分布より，投与された脂助は 主として脂肪組織内に眝蔵されており, 脂肪組 織内の RI 分布の差は燃焼率の差を反映してい るものと考之られた。

5 ) 無脂肪 TPN (A群) は肝内 TG 量が増 加しておう，脂肪合成が過剩に六進しているも のと考えられた。

6) 脂肪の多量投与時には盰内脂肪代謝は方 進していると考えられたが，外因性非蛋白熱源 の利用は糖質が多い場合に比し不良であり，こ のため肝・筋グリコーゲン值仕低值をとった。

7）以上より脂肪乳鼡の至適配合比は NPC の20〜40\%であろうと考えられた。

稿を終えるにあたり，御指導，御校閲を睗った恩 師寺本滋教授に感謝を捧げると共に，種々の助言と 御尽力をいただきました兽田益弘博士に深謝します。 また研究期間中たえす御協力と激励をくださった石 川治学兄に心から感謝いたします。

なお本論文の要旨注第22回日本外料代謝栄養学 会, 第 1 回日本静脈・経腸栄盖研究会において発表 Lた. 
文献

1) Dudrick SJ, Wilmore DW, Vars HM and Rhoads JE : Long term total parenteral nutrition with growth, development and positive nitrogen balance. Surgery (1968) 64, 134-142.

2) Schuberth $\mathrm{O}$ and Wretlind $\mathrm{A}:$ Intravenous infusion of fat emulsions, phosphatides and emulsifying agents. Acta Chir Scand (1961) 278 (Suppl), $1-21$.

3) Wretlind A : Complete intravenous nutrition theoretical and experimental background. Nutr Metab (1972) 14(Suppl), $1-57$.

4) Collins FD, Sinclair AJ, Royle JP, Coats DA, Maynard AT and Leonard RF : Plasma lipids in human linoleic acid deficiency. Nutr Metab (1971) 13, 150-167.

5) Tashiro T, Ogata H, Yokoyama H, Mashima Y and Iwasaki I : The effect of fat emulsion on essential fatty acid deficiency during intravenous hyperalimentation in pediatric patients. J Pediatr Surg (1975) 10, 203-213.

6) Tashiro T, Ogata H, Yokoyama H, Mashima $Y$ and Itoh $\mathrm{K}$ : The effect of fat emulsion (Intralipid) on essential fatty acid deficiency in infants receiving intravenous alimentation. J Pediatr Surg (1976) 11, 505-515.

7) O'Neil JA Jr, Caldwell MD and Meng HC : Essential fatty acid deficiency in surgical patients. Ann Surg (1977) 185, 535-542.

8 ）田代西彦，真島吉也，山森秀夫，林田和也，堀部和夫，奥井勝二：必須脂肪酸，小児外科 (1987) 19，1013 -1021 .

9) Jeejeebhoy KN, Anderson GH, Nakhooda AF, Greenberg GR, Sanderson I and Marliss EB : Metabolic studies in total parenteral nutrition with lipid in man. Comparison with glucose. J Clin Invest (1976) 57, 125-136.

10) Schuberth $O$ : Clinical experience with fat emulsions for intravenous use. Acta Chir Scand (1964) 325 (Suppl), 43-49.

11) Wretlind A : Vollständige parenterale Ernährung, Zeitschrift über die Ernährung des Gesunden und Kranken. (1968) 15(11 \& 12), 3-23.

12）小出来一博, 生形 圭: 栄美. 外科 (1969) 31，479-490.

13）山田栄一，木村信良，村上一登，具 栄作，佐藤忠敏，岡安 勲：静注用脂肪乳剂 Intrafatに関する研究 一 第 6 報：Intrafat 長期使用臨床例の検討。診断と治潦（1973）61，1691-1696.

14）石川 治, 大屋數啓司，池田昭彦，佐能量雄、柏 哲士，曾田益弘，寺本 滋：TPN下での脂肪乳剂の燃 焼率から見た至適配合比の検討. 外科と代謝・栄養 (1985) 19，213-214。

15) Folch J, Lees $M$ and Stanley GHS : A simple method for the isolation and purification of total lipids from animal tissues. J Biol Chem (1957) 226, 497-509.

16）奥山治美：脂質基礎分析法. 別冊 蛋白質核酸醅素，生体膜実験，上，共立出版株式会社，(1974）pp 121 -128 .

17）阿南功一, 紺野邦夫, 田村善蔵, 松橋通生, 松本重一郎：基礎生化学実験法，5, 化学的測定. 丸善株式会 社, (1976) pp 154-155.

18) Gornall AG, Bardawill CJ and David MM : Determination of serum proteins by means of the Biuret Reaction. J Biol Chem (1946) 177, 751-766.

19) Robinson HW and Hogden CG : The Biuret Reaction in the detemination of serum proteins. J Biol Chem (1940) 135, 707-725. 
20) Weichselbaum TE : An accurate and rapid method for the determination of proteins in small amount of blood serum and plasma. Am J Clin Pathol (1946) 10(Suppl), 40-49.

21) Yonetani $T$ : Studies on cytochrome oxidase. III. improved preparation and some properties. J Biol Chem (1961) 236, 1680-1688.

22）金井 泉, 金井正光：III非タンパク化合物，1非タンパク窒素 (NPN). 臨床搝查法提要, 金原出版株式会 社, 東京, pp 421-423.

23）石川 治, 大屋敷啓司, 池田昭彦, 佐能量雄, 柏 哲士, 曾田益弘、寺本 滋：TPN下における非蛋白熱 源の実効代謝率について。外科と代謝・栄養 (1986) 19，411-412,

24）赤沼安夫：糖代謝と脂質代謝の相関，ホルモンと臨床（1977）增刊，新内分流データブック下巻，pp 570 -571 .

25) Nordenström J : Utilization of exogenous and endogenous lipids for energy production during parenteral nutrition. Acta Chir Scand (1982) 510 (Suppl), $1-79$.

26）百瀬健彦, 芳田一宏, 前田正之, 古屋清一，近藤芳夫：手術侵撉と脂肪乳剂，ブドウ糖およびアラニンのエ ネルギー代謝における相互関係. 外科と代謝・栄盖（1981）15，97-102.

27）芳田一去：脂肪乳剤のエネルギー代謝に関する実験的研究。日外会誌（1982）83，709-722.

28）大柳治正：脂肪乳洬の代謝と臨床応用について. Med Postgrad (1977) 15，35-50.

29）大内清則，龟山仁人，塚本 長：高カロリー榆液下に㧍ける脂肪組織内肪質量および脂肪酸組成について。 日本静脈・経腸栄宦研究会誌 (1986) 1，62-63.

30) Fredrickson DS : Transport of fatty acids Physiol Rev (1958) 38, 585-630.

31）古賀禧子：仔犬における脂肪乳绪を含んだ完全静脈栄養の実験的研究一第 2 部：各蔵器の病理学的並びに 生化学的検討. 日小児外会誌 (1974) 9，685-703.

32) Kaminski DL, Adams A and Jellinek $M$ : The effect of hyperalimentation on hepatic lipid content and lipogenic enzyme activity in rats and man. Surgery (1980) 88, 93-100.

33）弓狩康三：糖，脂肪酸代謝に及ぼす不飽和脂助酸の効果．蛋・核・醭（1969）14，1308-1309.

34）田代亜彦，真島吉也，山森秀夫，林田和也，堀部和夫，太枝良夫，織田良雄，塚本哲也，西沢正彦、三沢博

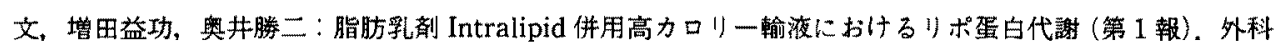
と代謝・栄養 (1985) 19，57-63.

35）田代互彦, 真島吉也, 山森秀夫, 林田和也, 昢部和夫, 太枝良夫, 織田良雄, 塚本哲也, 西沢正彦, 三沢博 文, 增田益功, 奥井腾二: 脂肪乳绪 Intralipid 併用高カロリー輸液におけるリポ蛋白代謝 (第 2 報)。外料 と代謝・栄萯 (1985) 19，330-336.

36）田代西彦, 真島吉也.山森秀夫, 堀部和夫、西沢正彦、真田正雄, 奥井勝二：肝障害と脂肪輸夜。外科治療 (1989) 61, 37-42.

37) 青木靖雄：経中心静脈栄養法によるカロリ一過量投与の妍に㧍ける影響. 日外会誌 (1978) 79, 1309-1323.

38）兽田益弘, 大屋数啓司, 石川 治, 柏 哲士, 佐能伊織, 池田昭彦, 古城昌義, 寺本 滋: 高力口リ一輸液 に扩ける脂肪乳唷の効果（II）. Med Postgrad (1985) 23，376-381.

39) Randle PJ, Garland PB, Hales $\mathrm{CN}$ and Newsholme EA : The glucose fatty-acid cycle its role in insulin sensitivity and the metabolic disturbance of diabetic mellitus. Lancet (1963) 1, 785-789.

40）大根田昭：グルカゴン. ホルモンと臨床（1980）堌刊，164-175.

41) Cahill GF Jr : Starvation in man. N Engl J Med (1970) 282, 668-675.

42) Saudek D and Felig $P$ : The metabolic events of starvation. Am J Med (1976) 60, 117-126.

43）石田数逐：TPN 継続下のアミノ酸代謝の実験的研究. 外科と代謝・栄盖 (1987) 21，112-124.

44) Bark $S$, Holm I, Hakansson I and Wretlind A : Nitrogen sparing effect of fat emulsion compared with glucose in the postoperative period. Acta Chir Scand (1976) 142, 423-427. 
45) Elwyn DH, Kinney JM, Gump FE, Askanazi J, Rosenbawm SH and Carpentier YA : Some Metabolic effects of fat infusions in depleted patients. Metabolism (1980) 29, 125-132.

46) Macfie J, Smith RC and Hill GL : Glucose or fat as a nonprotein energy source? A controlled clinical trial in gastroenterological patients requiring intravenous nutrition. Gastroenterology (1981) 80, 103-107. 


\title{
Experimental study of optimal fat/glucose ratio for total parenteral nutrition in rats
}

\author{
Akihiko IKEDA \\ Second Department of Surgery, \\ Okayama University of Medical School, \\ Okayama 700, Japan \\ (Director : Prof. S. Teramoto)
}

The optimal fat/glucose ratio for TPN was determined, using oxidation and distribution of ${ }^{14} \mathrm{C}$ labeled fat emulsion and glucose. Animals were divided into five groups according to percentage of energy supplied as fat $i \cdot$ e. $0 \%, 20 \%, 40 \%, 60 \%$ and $80 \%$, respectively.

${ }^{14} \mathrm{C}$-labeled fat emulsion and glucose were injected during TPN and the rate of oxidation to ${ }^{14} \mathrm{CO}_{2}$ as well as ${ }^{14} \mathrm{C}$ distribution in various organs were measured.

Oxidation of ${ }^{14} \mathrm{C}$-glucose was constant in all groups and that of ${ }^{14} \mathrm{C}$-labeled fat emulsion was inversely related to the amount of glucose administered simultaneously.

${ }^{14} \mathrm{C}$-distribution in adipose tissue was correlated to the amount of glucose infused. As oxidation of glucose was significantly higher than that of fat, the higher the fat content of non-protein calorie, the less oxidation was observed.

The groups given $60 \%$ and $80 \%$ energy composed of fat, showed less nitrogen retention and glycogen content in liver and muscle. These two groups exhibited high blood levels of free fatty acid, cholesterol and phospholipids.

These findings suggest that the optimal blending ratio of fat would be around $20-40 \%$ of the non-protein calories. 